\title{
EFEKTIVITAS PERANGKAP LALAT DARI BOTOL PLASTIK BEKAS KEMASAN AIR MINERAL DENGAN MENGGUNAKAN VARIASI UMPAN
}

\author{
Engel Panditan ${ }^{1)}$, Joy V. I. Sambuaga ${ }^{2)}$ \\ ${ }^{1)}$ Kantor Kesehatan Pelabuhan Kelas II Manado \\ ${ }^{2)}$ Jurusan Kesehatan Lingkungan Poltekkes Kemenkes Manado \\ Email: engel.panditan@yahoo.co.id
}

\begin{abstract}
Health disrupting flies belong to the order Diptera, suborder of Cyclorrhapha. Species that are important in human health are Musca domestica (house flies), Stomoxys calcitrans (cage flies), Calliphoridae (green flies), Sarcophaga sp (meat flies), Fannia sp (small flies). The purpose of this study was to determine the effectiveness of fly traps from used plastic bottles of mineral water using bait variations at the site NK Family research on Settlements Singkil 2 Neighborhood3. This research method was experimental where researchers wanted to know the fly trap with which bait from the three bait the most preferred fly. From the results of research on fly traps from used plastic bottles of mineral water by using fish, shrimp and bagasse waste feed, the most preferred bait for fish waste is 706 flies with an average of 141 flies. The results of this study were statistically tested using ANOVA test, for the type of fly trap with the most effective fish waste bait obtained a value of $p=0.037$. So it can be concluded that using fly traps from used plastic bottles of mineral water by using fish waste bait is one of the effective methods of controlling flies. Suggestions from community researchers are expected to trap flies from plastic bottles with fish waste bait in controlling flies at home.
\end{abstract}

Keywords: Effectiveness, Fly Trap

\begin{abstract}
Abstrak. Lalat pengganggu kesehatan tergolong kedalam ordo Diptera, subordo Cyclorhapha. Spesies yang penting dalam kesehatan manusia adalah Musca domestika (lalat rumah), Stomoxys calcitrans (lalat kandang), Calliphoridae (lalat hijau), Sarcopaga sp (lalat daging), Fannia sp (lalat kecil). Tujuan penelitian ini adalah untuk mengetahui efektivitas perangkap lalat dari botol plastik bekas kemasan air mineral dengan menggunakan variasi umpan dilokasi penelitian Keluarga $\mathrm{N}-\mathrm{K}$ pada Pemukiman Kelurahan Singkil 2 Lingkungan 3. Metode penelitian ini bersifat eksperimen dimana peneliti ingin mengetahui perangkap lalat dengan umpan mana dari ketiga umpan yang paling disukai lalat. Dari hasil penelitian perangkap lalat dari botol plastik bekas kemasan air mineral dengan menggunakan umpan limbah ikan, udang, dan ampas tebu, umpan limbah ikan paling disukai lalat yaitu 706 ekor lalat dengan rata-rata 141 ekor lalat. Hasil penelitian ini diuji statistik dengan menggunakan uji anova, untuk jenis perangkap lalat dengan umpan limbah ikan paling efektif memperoleh nilai $p=0,037$. Maka dapat disimpulkan dengan menggunakan perangkap lalat dari botol plastik bekas kemasan air mineral dengan menggunakan umpan limbah ikan adalah salah satu metode pengendalian lalat yang efektif. Saran dari peneliti masyarakat diharapkan dapat membuat perangkap lalat dari botol plastik dengan umpan limbah ikan dalam pengendalian lalat dirumah.
\end{abstract}

Kata Kunci : Efektifitas, Perangkap lalat

Pembangunan bidang kesehatan saat ini diarahkan untuk menekan angka kematian yang disebabkan oleh berbagai penyakit yang jumlahnya semakin meningkat. Masalah umum yang dihadapi dalam bidang kesehatan adalah jumlah penduduk yang besar dengan angka pertumbuhan yang cukup tinggi dan penyebaran penduduk yang belum merata, tingkat pendidikan dan sosial ekonomi yang masih rendah. Keadaan ini dapat menyebabkan lingkungan fisik dan biologis yang tidak memadai sehingga memungkinkan berkembang biaknya vektor penyakit (Kemenkes, 2010).
Dalam lingkungan pemukiman banyak jenis serangga yang harus dikendalikan walaupun tidak dapat diberantas secara tuntas antara lain adalah lalat. Keberadaan lalat menjadi indikator kebersihan tempat tersebut. Lalat sangat tertarik pada bau-bauan yang busuk, tumpukan sampah yang basah, sayuran, ikan, serta sisa-sisa potongan pada penjualan daging.

Lalat merupakan binatang pengganggu, dan beberapa spesies telah terbukti menjadi penular (vektor) penyakit. Keberadaan lalat disuatu tempat juga merupakan indikasi kebersihan yang kurang baik. Lebih dari 116.000 spesies lalat, beberapa diantaranya berbahaya 
bagi kehidupan manusia karena menularkan penyakit. Spesies yang penting dalam kesehatan manusia adalah Musca domestika (lalat rumah), Stomoxys calcitrans (lalat kandang), Calliphoridae (lalat hijau), Sarcophaga sp ( lalat daging), Fannia sp (lalat kecil). Lalat merupakan vektor penular penyakit terutama terjadi secara mekanis melalui tubuh bagian luar yaitu kaki, sayap, bulu pada tubuh dan secara biologis yaitu melalui muntahan dan kotorannya. Penyakitpenyakit yang dapat ditularkan oleh lalat diantaranya : Disentri, Cholera, Thypoid, Diare, Gatal-gatal pada kulit ( Sucipto, 2011 ). Upaya pengendalian lalat yang efektif yaitu semua kegiatan atau tindakan yang ditujukan untuk menurunkan populasi lalat.

Menurut penelitian Suprapto (2003) dalam Tanjung (2016), pengendalian lalat dengan menggunakan Fly trap sangat efektif dalam menurunkan tingkat populasi kepadatan lalat dengan menggunakan umpan udang basah selama lima hari dengan jumlah yang tertangkap ialah 14.654 dan bila di persentasekan jumlah lalat yang tertangkap hari pertama $100 \%$, hari kedua $60,31 \%$, hari ketiga $56,02 \%$, hari keempat $51,43 \%$, hari kelima 42,25\%.

Menurut Aini (2000) dalam Tanjung (2016) penggunaan Fly trap dengan umpan ampas tebu sangat efektif dalam menurunkan tingkat populasi kepadatan lalat dengan jumlah dimana jumlah yang sangat padat $42,31 \%$ menjadi $0,00 \%$, padat $46,15 \%$ menjadi $30,77 \%$ yang dilakukan ditiap rumah penduduk.

Menurut Tanjung (2016) penggunaan Fly trap dengan umpan Udang basah, Insang ikan, dan ampas tebu sangat efektif dalam pengendalian lalat dimana Fly trap berbentuk bulat dalam pengukuran selama 3 hari di dapatkan masing-masing umpan udang basa 353 ekor rata-rata 118 ekor, insang ikan 518 ekor rata-rata 173 ekor, ampas tebuh 245 ekor ratarata 82 ekor. Berdasarkan uraian diatas penulis ingin melakukan penelitian tentang:

"Efektivitas Perangkap Lalat Dari Botol Plastik Bekas Kemasan Air Mineral Dengan
Menggunakan Variasi Umpan ".Tujuan penelitian ini adalah untuk mengetahui Efektivitas Perangkap Lalat Dari Botol Plastik Bekas Kemasan Air Mineral Dengan Menggunakan Variasi Umpan dilokasi penelitian Keluarga N-K pada Pemukiman Kelurahan Singkil 2 Lingkungan 3.

\section{Metode}

Jenis penelitian ini adalah Pre-Eksperimen Designs (one-shot case study) karena desain ini belum merupakan eksperimen sungguh-sungguh (Sugiyono, 2014). Dengan rancangan penelitian sebagai berikut :

Keterangan

\section{O}

$\mathrm{X}=$ Perangkap lalat dari botol plastik bekas kemasan air mineral dan variasi umpan (udang, ampas tebu, dan limbah ikan).

$\mathrm{O}=$ Jumlah lalat yang tertangkap pada pengulangan selama 5 hari.

Variabel dalam penelitian ini yaitu perangkap lalat dari botol plastik bekas kemasan air mineral ukuran $1500 \mathrm{ml}$ dan variasi umpan (udang, ampas tebu, dan limbah ikan). Objek penelitian ini adalah Perangkap lalat dari botol plastik bekas kemasan air mineral dengan menggunakan variasi umpan (limbah ikan, udang, dan, ampas tebu). Data yang di dapat dari hasil penelitian dianalisa, diolah, disajikan dalam bentuk tabel dan grafik kemudian diuji dengan menggunakan hasil uji one way anova, dinarasikan kemudian ditarik suatu kesimpulan.

\section{Hasil}

Penelitian dilaksanakan selama 5 hari yaitu mulai dari hari senin tanggal 11 Juni sampai dengan hari jumat tanggal 15 Juni. Pelaksanaan penelitian dimulai dari jam $07.00-17.00$. Dengan hasil penangkapan sebagai berikut : Hasil penelitian perangkap lalat yang terbuat dari botol plastik bekas kemasan air mineral dengan menggunakan variasi umpan seperti di tabel berikut ini: 
Tabel 1. Hasil Perbandingan Jumlah Lalat Yang Masuk Pada Perangkap Lalat Dari Botol Plastik Bekas Kemasan Air Mineral Dengan Menggunakan Umpan Limbah Ikan, Udang, dan Ampas Tebu.

\begin{tabular}{crcccc}
\hline & & \multicolumn{3}{c}{ Umpan } & Jumlah \\
\cline { 3 - 5 } No & Hari & Limbah Ikan & Udang & Ampas Tebu & 410 \\
\hline 1 & Hari ke 1 & 204 & 189 & 17 & 340 \\
2 & Hari ke 2 & 179 & 149 & 12 & 251 \\
3 & Hari ke 3 & 116 & 125 & 10 & 215 \\
4 & Hari ke 4 & 110 & 100 & 5 & 148 \\
5 & Hari ke 5 & 97 & 84 & 3 & 280 \\
\hline
\end{tabular}

Berdasarkan tabel 1 dapat dilihat perangkap lalat dari botol bekas kemasan air mineral dengan umpan limbah ikan dari hari ke 1 sampai hari ke 5 berjumlah 706 ekor lalat ratarata 141 ekor lalat, dengan umpan udang dari hari ke 1 sampai hari ke 5 berjumlah 647 ekor lalat rata-rata 129 ekor lalat, dengan umpan ampas tebu dari hari ke 1 sampai hari ke 5 berjumlah 47 ekor lalat rara-rata berjumlah 9 ekor lalat.

Hasil tangkapan perangkap lalat dari botol plastik bekas kemasan air mineral dengan menggunakan variasi umpan dapat juga berbentuk grafik seperti dibawah ini:

Gambar 1. Perbandingan Jumlah Lalat Yang Masuk Pada Perangkap Lalat Dari Botol Plastik Bekas Kemasan Air Mineral Dengan Menggunakan Umpan Limbah Ikan, Udang, dan Ampas Tebu.

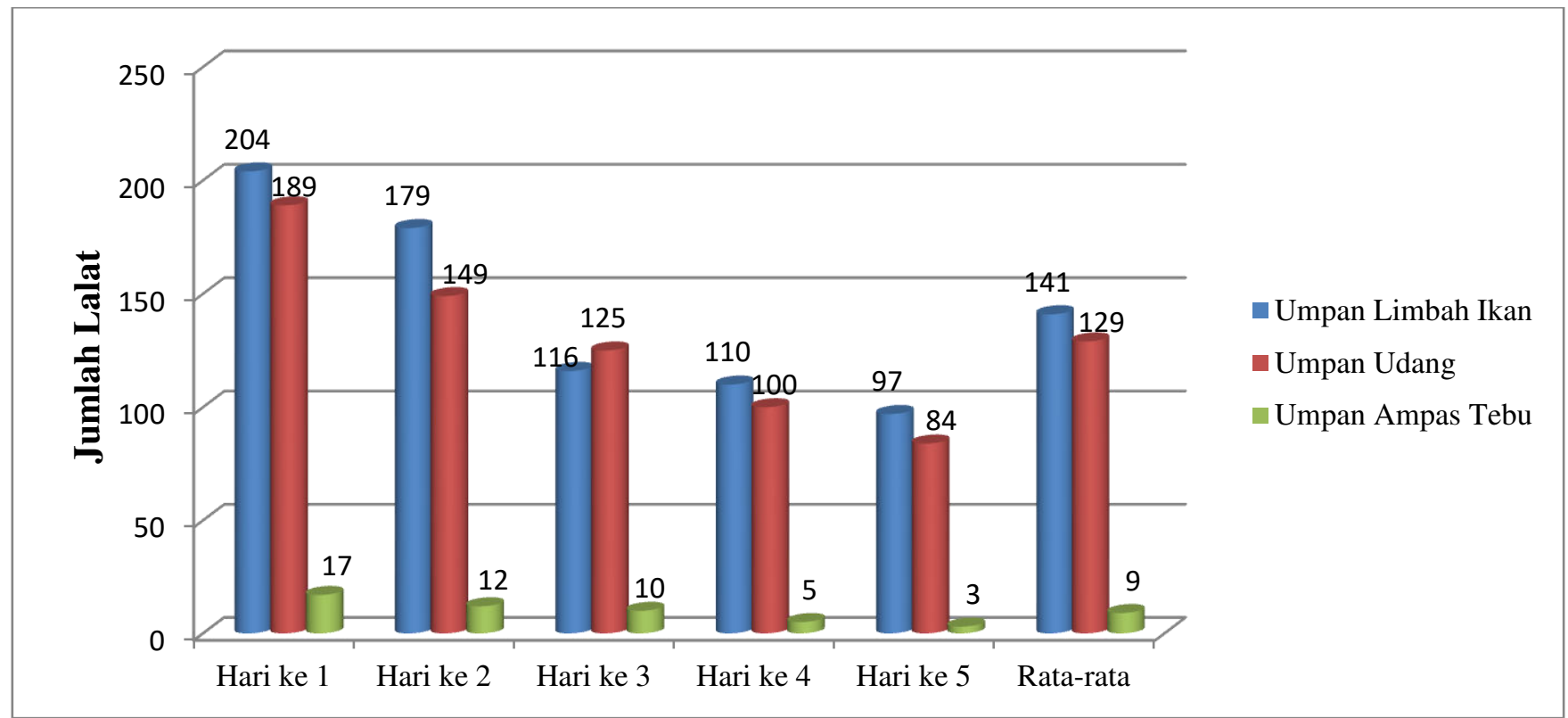

Berdasarkan gambar 1 dapat dilihat bahwa perangkap lalat dari botol bekas kemasan air mineral dengan mengunakan umpan limbah ikan, udang dan ampas tebu dari hari ke hari mengalami penurunan. 
Tabel 2. Hasil Uji Anova

\begin{tabular}{cccc}
\hline Umpan & Mean Square & F & Sig \\
\hline Limbah ikan & 165,250 & 26,034 & 0,037 \\
Udang & 556,250 & 5,185 & 0,046 \\
Ampas tebu & 12,500 & 4,008 & 0,200 \\
\hline
\end{tabular}

Berdasarkan tabel 2 dapat dilihat perangkap lalat dari botol plastik bekas kamasan air mineral dengan menggunakan variasi umpan efektif dalam menangkap lalat. Hasil uji statistik dengan menggunakan uji anova, untuk jenis perangkap lalat dengan umpan limbah ikan paling efektif memperoleh nilai $p=0,037$. Ini menunjukkan bahwa ada perbedaan antara penggunaan perangkap lalat dengan ke 3 jenis umpan antara umpan limbah ikan, udang dan ampas tebuh.

\section{Pembahasan}

Dari hasil penelitian yang dilaksanakan di Kelurahan Singkil Dua Lingkungan 3 pada Keluarga N-K salama 5 hari, lalat yang tertangkap dari hari ke hari mengalami penurunan. Perangkap lalat dari botol plastik bekas kemasan air mineral dengan umpan limbah ikan, udang, dan ampas tebu dengan jumlah yang tertangkap yaitu 1400 ekor lalat dan perangkap lalat dari botol plastik bekas kemasan air mineral dengan umpan limbah ikan paling banyak disukai lalat yaitu 706 ekor lalat rata-rata 141 ekor lalat, dengan umpan udang 647 ekor lalat rata-rata 129 ekor lalat, dan dengan umpan ampas tebu 47 ekor lalat rata-rata 9 ekor lalat.

Botol plastik bekas kemasan air mineral merupakan sampah padat buangan dari kegiatan manusia yang sudah terpakai dan dipakai lagi untuk pembuatan perangkap lalat, ini merupakan salah satu dari prinsip-prinsip pengolahan sampah yaitu Reuse (penggunaan kembali) menggunakan kembali barang-barang yang bisa digunakan. Kelebihan perangkap lalat dari botol plastik bekas kemasan air mineral dengan umpan limbah ikan sangat efektif dan praktis dimana botol $1500 \mathrm{ml}$ bisa di temukan dimana-mana terutama ditempat sampah, pembuatanya pun sangat mudah dan limbah ikan bisa diambil dari pembersihan ikan yang kita beli dari pasar atau kita dapat dari laut, sungai, danau, telaga, sehingga keduanya bisa digunakan dalam pengendalian lalat dirumah. Kekurangan perangkap lalat dari botol plastik bekas kemasan air mineral dengan umpan limbah ikan adalah gangguan atau bisa dibawah oleh binatang peliharaan seperti anjing dan kucing karena bau yang dihasilkan dari limbah ikan.

Pemasangan perangkap lalat diletakkan di depan rumah dan belakang samping rumah sebagai barier atau penghalang, sehingga lalat sebelum masuk dalam rumah atau dapur dapat masuk dalam perangkap yang dibuat manusia. Meskipun masih ada lalat yang masuk. Pengendalian lalat di rumah dilakukan karena lalat memiliki sifat sebagai penggangu dan sebagai pembawa penyakit atau vektor yang sangat merugikan manusia. selain itu kehadiran lalat dirumah merupakan estetika yang kurang baik terkesan jorok akibatnya dapat menjadi sumber komplain bagi tamu yang sedang berkunjung.

Pemasangan perangkap di TPS dan TPA dilakukan karena berdekatan dengan pemukiman, untuk TPS berjarak \pm 200 meter dan TPA \pm 20 meter dari tempat penelitian. jarak inilah yang memungkinkan lalat untuk berpindah tempat dari tempat sampah ke rumah-rumah penduduk. Umumnya daya terbang lalat tidak lebih dari 50 meter dari tempat perindukannya, kecuali kalau keadaan memaksa maka dapat terbang beberapa kilometer (Sucipto, 2011). TPA yang dimaksud disini adalah tempat pembuangan akhir dari beberapa keluarga yang berdekatan dengan lokasi rumah penelitian yang kadang-kadang membuang sampah di tempat tersebut walaupun sudah dilarang namun masih ada keluarga yang membuang sampah disitu baik sampah kering maupun sampah basah sehingga memungkinkan lalat untuk berkembang biak dan selanjutnya akan berpindah tempat ke rumah warga disekitanya (Poluakan, 2014)

Dari hasil penelitian Lalat sangat menyukai limbah ikan karena baunya yang menyengat, memiliki darah, mengandung 
berbagai nutrien yaitu: Nitrogen, Pospor, Kalium (Hapsari \& Welasi 2013). Sehingga mengundang kehadiran lalat untuk masuk dalam perangkap.

Menurut penelitian Tanjung (2016) penggunaan Fly trap berbentuk bulat dengan memakai umpan insang ikan sangat efektif dalam pengendalian lalat dimana pemasangan dilaksanakan selama 3 hari didapatkan 518 ekor lalat rata-rata 173 ekor. Menurutnya Lalat sangat menyukai insang ikan karena mengandung darah baunya sangat khas dan menyengat. Lalat juga menyukai makanan yang sedang mengalami proses fermentasi/pembusukan dan lalat sangat menyukai makanan yang cair atau makanan yang basah.

Dari hasil penelitian yang dilakukan umpan udang berjumlah 647 ekor lalat rata-rata 129 ekor lalat. Umpan udang disukai lalat dan hanya memiliki perbandingan sedikit dengan limbah ikan. Umpan udang juga mudah didapatkan dan proses pembuatan perangkap mudah dan sederhana. udang juga memiliki kandungan protein berkualitas tinggi omega-3, karbohidrat, lemak, air, abu, asam amino esensial, asam amino non esensial (Gunalan et al. 2013). Bau yang dihasilkan dari udang pun sangat menyengat sehingga mengundang kehadiran lalat.

Menurut penelitian Suprapto (2003) pengendalian lalat dengan menggunaan Fly trap dan umpan udang basah sangat efektif dalam pengendalian lalat dimana pemasangan perangkap dilakukan selama 5 hari dan jumlah yang tertangkap adalah 14.654 ekor lalat. Ini dikarenakan aroma yang khas dan bau yang dihasilkan dari kepala udang sehingga menarik lalat untuk datang dan masuk dalam perangkap yang dibuat manusia.

Hasil Penelitian yang dilakukan selama 5 hari umpan ampas tebu dengan jumlah lalat yang tertangkap adalah 47 ekor lalat rata-rata 9 ekor lalat, dan bila dilihat dari hari ke hari mengalami penurunan, Ini disebabkan ampas tebu kurang disukai lalat karena tidak memiliki bau.

Menurut penelitian Aini (2000) penggunaan Fly trap dengan umpan ampas tebuh sangat efektif dalam pengendalian lalat dimana jumlah yang sangat padat $42,31 \%$ menjadi $0,00 \%$ dan padat $46,15 \%$ menjadi $30,77 \%$. Ini dikarenakan ampas tebu merupakan makan yang manis sehingga lalat sangat menyukai makanan yang dimakan manusia seperti gula dan susu. Selain itu ampas tebuh juga memiliki kandungan selulosa, hemiselulosa,dan lingin (Samsuri et al 2007).

Jadi dari hasil penelitian perangkap lalat dari botol bekas kemasan air mineral dengan menggunakan variasi umpan, (limbah ikan, udang, dan ampas tebu) yang paling efektif adalah perangkat lalat dengan umpan limbah ikan.

Berdasarkan hasil uji statistik dengan menggunakan uji anova, untuk jenis perangkap lalat dengan umpan limbah ikan paling efektif memperoleh nilai $p=0,037$. Maka dapat disimpulkan bahwa Perangkap lalat dari botol plastik bekas kamasan air mineral dengan menggunakan umpan limbah ikan, udang, dan ampas tebu, ada perbedaan dalam penangkapan lalat.

\section{Kesimpulan}

Berdasarkan hasil penelitian pada Keluarga N-K di Kelurahan Singkil 2 Lingkungan 3, pemasangan perangkap lalat dari botol plastik bekas kemasan air mineral dengan umpan limbah ikan, udang, dan ampas tebu, yang paling disukai lalat adalah perangkap lalat dengan umpan limbah ikan dan hasil uji statistik dengan menggunakan uji anova, untuk jenis perangkap lalat dari botol plastik bekas kemasan air mineral dengan umpan limbah ikan paling efektif.

\section{Saran}

1. Masyarakat menggunakan perangkap lalat dari botol plastik bekas kemasan air mineral ukuran $1500 \mathrm{ml}$ dengan umpan limbah ikan dalam pengendalian lalat di rumah.

2. Mengantisipasi dengan adanya gangguan dari binatang peliharaan seperti kucing dan anjing, perangkap lalat perlu digantung.

3. Keluarga-keluarga yang ada di Pemukiman Singkil 2 Lingkungan 3 khususnya yang berdekatan dengan lokasi rumah penelitian agar mengolah sampah dengan baik supaya tidak mengundang kehadiran lalat sehingga lalat tidak bisa bekembang biak dengan cepat.

4. Bagi peneliti selanjutnya dapat meneliti bentuk atau variasi perangkap lalat. 


\section{Daftar Pustaka}

Aini, Natijul, 2000. Efektifitas penggunaan tingkat kepadatan populasi lalat di Desa Namo Bintang Kecamata Pancur Batu Kabupaten Deli Serdang, Skripsi, FKM USU. Medan.

Gunalan, B., Nina T. S., Soundarapandian. P., \& Anand, T. 2013. Nutritive Value of Cultured White Leg Shrimp Litopenaeus Vannamei, CAS in Marine Biology, Faculty of Marine Sciences, Annamalai University, Parangipettai, Tamil Nadu.

Hapsari, N. \& Welasi, T. (2013). Pemanfaatan Limbah Ikan Menjadi Pupuk Organik. Jurnal Teknik Lingkungan, 2(1), 1-6.

Keputusan Menteri Kesehatan RI No 431/MENKES/SK/IV/2007 Tentang Pedoman Teknis Pengendalian Resiko Kesling Pelabuhan/Bandara/Pos Lintas Batas Dalam Rangka Karantina Kes.

Poluakan, Marsel, 2014. Tingkat Kepadatan Lalat Dipasar Motoling Kecamatan Motoling Kabupaten Minahasa Selatan Tahun 2014, Karya Tulis Ilmiah, Jurusan Kesling. Poltekkes Kemenkes Manado.
Samsuri, M., Gozam, M., Mardias, R., Baiquni, M., Hermansyah, H., Wijanarko, A., Prasetya, B., \& Nasikin, M. 2007. Pemanfaatan Sellulosa Bagas Untuk Produksi Ethanol Melalui Sakarifikasi dan Fermentasi Serentak Dengan Enzim Xilanase, Makara Teknologi.

Sucipto, Cecep Dani, 2011. Vektor Penyakit Tropis, Gosyen Publising, Yogyakarta.

Sugiyono, 2014. Metode Penelitian Kuantitatif Kualitatif dan $R \& D$, Alfabeta, Bandung.

Suprapto, 2003. Efektifitas Pengendalian Lalat Rumah ( Musca Domestika) Dengan Menggunakan Fly Trap Pada Parameter Kantor Kesehatan Pelabuhan Dumai, Skripsi Kesehatan Masyarakat, Universitas Sumatera Utara. Medan.

Tanjung, Nelson, 2016. Efektifitas Berbagai Bentuk Fly Trap Dan Umpan Dalam Pengendalian Kepadatan Lalat Pada Pembuangan Sampah Jalan Budi Luhur Medan Tahun 2016, Skripsi, Jurusan Kesehatan Masyarakat. Poltekkes Medan. Medan. 